\title{
ARCHITECTURE, RITUALS, AND NORMS IN CIVIL PROCEDURE
}

\author{
Fabien Gélinas* \\ Clément Camion ${ }^{* *}$ \\ Karine Bates** \\ Emily Grant ${ }^{* * *}$
}

In this article, the authors identify two important gaps in the literature on civil justice reform, both of which relate to the concept of stability in the law as an added value of public adjudication. The article aims to suggest avenues for future research on civil justice reform, especially in light of increasing recourse to private modes of dispute resolution. First, the article draws attention to the role played by judicial rituals and architecture in court-based, public adjudication, as a means of generating stability in the law and enhancing the legitimacy of dispute resolution. Second, from a more theoretical perspective, the article brings out the added value of formulating and formalizing legal norms through a public adjudicative process. Stability in the law encourages human agency and dignity by permitting individuals to form expectations and make decisions about their lives, acting in reliance on the law and the values that the law promotes. The value of stability must be taken into account in future research and policy work on civil justice reform, particularly as private justice, which lacks many of the characteristics that encourage stability in public adjudication, is increasingly explored as a potential solution to problems of access to justice.

Dans cet article, les auteurs analysent deux lacunes importantes qu'ils ont relevées dans la littérature concernant la réforme de la justice civile et qui gravitent autour du concept de la stabilité du droit en tant qu'avantage découlant du processus public de règlement des différends. Les auteurs proposent des sujets

* Sir William C. Macdonald Professor of Law at McGill University and a co-founder of the Montreal Cyberjustice Laboratory. His research spans private and public law in both the civilian and the common law traditions. Formerly General Counsel of the International Court of Arbitration of the International Chamber of Commerce, he is a member of the Quebec Bar and acts as an arbitrator and a consultant on dispute resolution and legal reform. The preparation of this text was made possible by a grant from the Social Sciences and Humanities Research Council of Canada [SSHRC] and the Fonds de recherche du Québec-Société et culture [FRQSC].

** Lawyer specializing in clear communication of the law. He is a double graduate of McGill University, Faculty of Law (B.C.L./LL.B.), and he holds a degree in political science and philosophy from Université de Montréal. He was admitted to the New York Bar in 2015 and is seeking admission to the Quebec Bar in 2016.

*** B.C.L., LL.B., Ph.D., professor of anthropology at Université de Montréal. Her research tackles issues of access to justice with a focus on India, with the double purpose of understanding diversity in discourses and practices relating to access to justice, and of analyzing interactions between formal and informal instances of dispute resolution.

${ }^{* * * *}$ Research Associate, McGill Private Justice and the Rule of Law Research Team. She holds a B.C.L./LL.B. from the McGill University Faculty of Law and is a member of the Quebec Bar. 
à explorer lors de futures recherches sur la réforme de la justice civile, eu égard, notamment, au recours croissant aux modes privés de règlement des différends. Dans un premier temps, ils soulignent que les rituels et l'architecture du système judiciaire public favorisent la stabilité du droit et rehaussent la légitimité $d u$ règlement des différends. Examinant ensuite la question sous un angle plus théorique, ils s'attardent aux avantages découlant de la formulation et de l'officialisation des normes juridiques dans le cadre du processus public de règlement des différends. La stabilité du droit favorise l'intervention et la dignité humaines, car elle permet aux personnes d'avoir des attentes et de prendre des décisions au sujet de leurs vies en se fondant sur les règles de droit et sur les valeurs qui les sous-tendent. L'atout que représente la stabilité doit être pris en compte dans les futurs travaux de recherche et d'orientation sur la réforme de la justice civile, surtout à l'heure où la justice privée, qui est dépourvue de bon nombre des caractéristiques qui engendrent la stabilité dans le processus public de règlement des différends, est de plus en plus explorée comme solution possible aux problèmes d'accès à la justice.

\section{INTRODUCTION}

Thinking about the future of civil justice raises a number of difficult questions regarding how civil procedure ought to look and which values it ought to promote. In this article, we identify two significant gaps in the literature that has attempted to answer these questions, both of which concern the idea of stability in the law as an added value of the public adjudication of disputes. Our aim is to suggest potential avenues for future research on civil justice reform, especially in light of increasing recourse to private modes of dispute resolution as a means of promoting access to justice.

We first offer a critical analysis of the role of form in generating stability in the law, particularly through judicial rituals and architecture associated primarily with public adjudication (Part II). With respect to judicial rituals, stability is enhanced through procedures that shape participants' perceptions of authority and power, recourse to violence, and rationality, legitimizing the decision-making process and its values. Regarding judicial architecture, the visual features of courtrooms and courthouses have a role in conveying values that underlie and legitimize the justice system. In private dispute resolution, we posit that party participation may help to fill the legitimizing role played by ritual and architecture, where these latter features are less pronounced.

From a more theoretical perspective, we then draw out the added value - in terms of bringing about stability in the law for the benefit of individuals - of formulating and formalizing legal norms through a public adjudicative process, which we argue has been overlooked in traditional positivist and interpretivist approaches to inherent indeterminacy in the law (Part III). We examine the potential for tension, when faced with indeterminacy, between the value of rendering a factually accurate decision and the value of simply rendering a decision in itself, even if erroneous. We argue that the latter has value for the public in the form of normative 
accuracy, by contributing to the clear articulation of a legal norm on which members of the public can rely.

Stability in the law favours human agency and dignity by permitting individuals to form expectations and make decisions about their lives, acting in reliance on the law and the values that the law promotes. It is a value that must be taken into account in future research and policy work on civil justice reform, particularly as private justice, which lacks many of the characteristics that encourage stability in public adjudication, is increasingly seen as a potential solution to problems regarding access to justice.

\section{JUSTICE MUST BE SEEN TO BE DONE: FORM AND LEGITIMACY IN JUDICIAL RITUALS AND ARCHITECTURE}

The words of Lord Hewitt in an English decision of 1924 are among the most quoted in law: "[J]ustice should not only be done, but should manifestly and undoubtedly be seen to be done."1 Yet, with respect to judicial rituals and judicial architecture, this is an aspect of civil procedure that seems to have been overlooked in the literature on civil justice reform. On the one hand, students of civil procedure have tended to think in terms of procedural arrangements and, more recently, in terms of management strategies when aiming to improve the courts' case flow, particularly through managerial judging. This branch of the literature tends to be favourable to alternative dispute resolution [ADR], settlement, and courthouse reforms aimed at emptying case dockets. ${ }^{2}$ On the other hand, many authors have focused on the substantive quality of justice. ${ }^{3}$ Some have emphasized the judicial system's legitimacy as an important value. ${ }^{4}$ Given the complexity of combining both quantitative and qualitative analysis, however, studies have often, for methodological reasons, restricted the analysis to principled understandings of the rule of law. ${ }^{5}$ Social psychologists have found a middle ground between approaches that are too principled or too managerial by analyzing users' satisfaction both in the short and long run. ${ }^{6}$

Overall, little attention has been paid to dispute resolution mechanisms' judicial rituals. In instances where judicial rituals and architecture have been considered, authors often take for granted the need for a ritualized adjudicative process within a dedicated space, displaying a certain bias in favour of symbolism, rituals, and judicial architecture as well as seeing public adjudication as a more genuine track for civil justice. One notable exception lies in the works of Judith Resnik, who strives to articulate a democratic theory capable of justifying the relevance of public adjudicatory processes, with a truly critical take on how the "vanishing trial" phenomenon

\footnotetext{
$R v$ Sussex Justices, Ex parte McCarthy (1923), [1924] 1 KB 256, 259.

The best critical account is probably found in Elizabeth G Thornburg, "The Managerial Judge Goes to Trial" (2010) 44 U Rich L Rev 1261.

3 See eg European Commission for the Efficiency of Justice, Quality Management in Courts and in the Judicial Organisations in Eight Council of Europe Member States (Strasbourg, Austria: Council of Europe, 2010).

$4 \quad$ See eg Laurens Walker et al, "Reactions of Participants and Observers to Modes of Adjudication" (1974) 4 J Applied Soc Psychol 295 (examining factors influencing legitimacy and resulting feeling of justice).

5 See eg The World Justice Project Rule of Law Index, 2014 (Washington, DC: World Justice Project, 2014), online: World Justice Project $<$ http://worldjusticeproject.org/rule-of-law-index $>$.

6 Tom R Tyler, Why People Obey the Law (Princeton, NJ: Princeton University Press, 2006).
} 
has reconfigured dispute resolution processes, outsourced a large part of the adjudicative function of courts, and reduced our understanding of public justice to the terms of rights of access. $^{7}$ Overall, however, there is a lack of literature on the comparative costs and benefits of highly ritualized versus more informal processes and, incidentally, of public versus private justice. In other words, the added value of rituals and architecture needs to be further assessed. One method of inquiry is to consider the role played by "form" in fostering the foreseeability, predictability, and stability of the law and, ultimately, its perceived legitimacy.

\section{A. Judicial Rituals}

What is a ritual? Is it purely a matter of form? Is it "formal form," despite the apparent tautology? On the contrary, are rituals better understood through the specific effects they have on their subjects? Can any kind of judicial process be a ritual? Is there a meaningful difference between a whole ritual and the sum of its ritualistic parts - that is, a difference between the process and its performance? From the Latin ritualis and ritus, "ritual" designates a religious or solemn ceremony consisting of a series of actions performed in a prescribed order. The rite is the ceremony, and the ritual is the precisely regulated process by which the ceremony is held. A ritual is at times constitutive of a rite, and, at times, it conforms to a rite, according to a seemingly contradictory, but really dialectical, logic of constitutive moments. Interestingly, the term "ritual" may also designate a book prescribing the administration of religious or ceremonial rights. This usage of "ritual" has been applied to papyrus and temple engravings prescribing the organization and order of Ancient Egypt's ceremonies. ${ }^{8}$ Here, we will not go as far as to assert that written rules are rituals.

Beyond the religious context, "ritual" now commonly refers to any activity that is mandatorily organized in a precise manner - the ensemble of rites, rules, and practices of a religion, association, or community. We can thus speak indistinctively of the ritual of a presidential election and the ritual of tooth brushing. A ritual is a practice or activity that is systematically performed and that has crystallized in a given pattern. Rituals are essentially social constructs and thus produce certain effects. They shape people's behaviour in public. In this respect, legal scholar Daniel Jutras notes an ontological continuity between what Michael Reisman has labelled "law in brief encounters" and larger legal systems. ${ }^{9}$ In the same vein, sociologist Erving Goffman has shown how our fundamental need to appear coherent and save face in social interactions is fulfilled when abiding by rituals - that is, the implicit code of conduct of a given community and the common expectation that such a code will be upheld by participants. ${ }^{10}$ Goffman further shows that rituals can be used to "frame" a particular situation in order to

7 Judith Resnik, "Courts: In and Out of Sight, Site, and Cite" (2008) 53 Vill L Rev 771; Judith Resnik \& Dennis E Curtis, Representing Justice: Invention, Controversy and Rights in City-States and Democratic Courtrooms (New Haven, CT: Yale University Press, 2011).

8 The Oxford English Dictionary, 3d ed, sub verbo "ritual"; Trésor de la langue française informatisé, sub verbo "rituel", online: Centre national de ressources textuelles et lexicales <www.cnrtl.fr/definition/rituel $>$.

9 Daniel Jutras, "The Legal Dimensions of Everyday Life" (2001) 16 CJLS 45; W Michael Reisman, Law in Brief Encounters (New Haven, CT: Yale University Press, 1999).

10 See generally Erving Goffman, Interaction Ritual: Essays on Face-to-Face Behavior (Garden City, NY: Doubleday, 1967). 
organize people's experiences and manage their impressions. ${ }^{11}$ Judicial rituals play that role of staging authority and power.

In summation, then, the present article proposes a definition of "ritual" that accounts for both form and effect, considering these two dimensions of ritual to be interdependent to some degree. As discussed above, the effect of ritual - that is, its normativity as an implicit code of conduct is at least in part a function of a repeated form, process, or pattern of conduct, generating the expectation that the code will be upheld. At the same time, as Goffman highlights, the normative dimension of ritual can also be deployed to manage or organize behaviour and, therefore, has the potential to shape the pattern of conduct that constitutes a ritual's form. For the purposes of this article, the definition of ritual is broad, but it is intended to include rules of civil procedure and evidence, in both public and private forums for dispute resolution, to the extent that these rules reflect patterns of repeated conduct with normative effect. Private justice is, however, generally perceived to rely on fewer rituals than its public counterpart. While a vast number of judicial rituals may have a role to play in shaping understandings of the judicial system in diverse ways, this article will examine the specific cases of judicial ritual's ability to condition participants' perceptions of authority and power, recourse to violence, and rationality in the context of dispute resolution.

\section{Rituals in Judicial Procedure: Legitimizing Authority and Power}

For some, the particular order of justice that rituals depict, often characterized by values of neutrality and impartiality, may not matter. Rather, simply by imparting material reality to the law, rituals enable the law to fulfill the function of responding to a foundational human need for order. ${ }^{12}$ In other words, rituals fundamentally play the performative role of creating order out of chaos. The function of rituals in organizing any activity cannot be denied and is certainly of importance. In addition to imposing order, however, judicial rituals carry meaning because of the precise form of ordering that they impose.

A number of authors point to the way judicial rituals condition their participants. Rituals and architecture manage participants' perceptions and feelings regarding a subjectively held belief in the legitimacy of the judicial system. Myron Gochnauer, for instance, writes that judicial rituals such as taking an oath or putting on a gown give witnesses a sense of the momentous character of the judicial process and of the respect that it deserves, thus creating a beneficial psychological effect. ${ }^{13}$ Authority, then, is a form of "impression management," carried out through decorum, the oath practice, and spatial organization, as well as procedural arrangements, such as the way in which expert testimony is generally orchestrated. ${ }^{14}$

11 Erving Goffman, Frame Analysis: An Essay on the Organization of Experience (Cambridge, MA: Harvard University Press, 1974).

12 Guy Rocher, Étude de sociologie du droit et de l'éthique (Montreal: Thémis, 1996) at 10, 256-257.

13 Myron Gochnauer, "Swearing, Telling the Truth, and Moral Obligation" (1983) 9 Queen's LJ 199 at 203-205.

14 David Asma, "Genuflecting at the Bench: Rituals of Power and Power of Rituals in American Courts" 5 Red

Feather Journal of Postmodern Criminology, online: Critical Criminology $<w w w . c r i t c r i m . o r g / r e d-$

feather/journal-pomocrim/Vol-5-Dramaturgy/genuflecting_at_the_bench.htm>. 
In theory, procedural formalism is intended to safeguard both impartial decision making and equal opportunity of the parties. For Jessie Allen, procedural formalism acts as a constraint on practitioners' behaviours. ${ }^{15}$ In our view, the constraint of formalism pulls the practitioner and the decision maker out of their usual thought processes, replacing subjectively held conceptions with ones that are externally defined - at least to the extent that such conceptions are relevant to deciding the case at hand. A great deal of procedural rules are intended to reduce bias, to ensure that decisions are grounded in existing law and based on the merits of cases. Respect for formal procedures hints at a broader adherence to the rule of law, though perhaps one that is only unconscious at times.

Formalism also aims to level the procedural playing field between parties by imposing an impartial superseding power. Critical legal scholars such as Richard Delgado showed, quite early on, that people who hold prejudicial attitudes are more prone to act on those attitudes in informal settings rather than in formal settings. Informal settings are not always robust enough to shift pre-existing imbalances of power, and they are only a viable option where the parties are of comparable status to begin with. ${ }^{16}$ The argument may be taken further; discrimination may occur not only outside the law but also under the law and in the law. Rituals, including procedural formalism, have the potential to frame the parties' powerlessness. ${ }^{17}$ In this respect, language plays an important role in replicating pre-existing power structures. ${ }^{18}$

This does not mean that rituals are intrinsically weak, random, or generally flawed. For French magistrate and prolific author Antoine Garapon, judicial rituals are a "condition of possibility" for law. Although, in and of themselves, rituals do not offer any guarantee of justice - they can be circumvented and abused, sometimes even turned into farce - Garapon argues against desacralizing judicial rituals. Rather, he proposes the difficult task of reinventing judicial rituals by accounting for their role while remaining critical of their particular forms. ${ }^{19}$ Judicial rituals should not reinforce pre-existing power structures. Ideally, rituals should check overt

15 "[F]ormal legal procedures may limit the behavior of judicial decisionmakers in ways that could be seen as an embodiment of the rule of law." Jessie Allen, "Blind Faith and Reasonable Doubts: Investigating Beliefs in the Rule of Law" (2001) 24 Seattle UL Rev 691 at 716.

16 Richard Delgado et al, "Fairness and Formality: Minimizing the Risk of Prejudice in Alternative Dispute Resolution" (1985) 6 Wis L Rev 1359. Others have argued, however, that informal settings such as mediation may be better able to redress power imbalances than courts, given mediators' specific training in handling such matters. See eg Robert A Baruch Bush \& Joseph P Folger, The Promise of Mediation: The Transformative Approach to Conflict, rev ed (San Francisco: Wiley, 2005) at 9-10. This may be particularly true where parties are self-represented, an increasingly common phenomenon.

17 Asma, supra note 14 at 3, 7, 10.

18 Ibid; John M Conley \& William M O’Barr, Just Words: Law, Language, and Power (Chicago: University of Chicago Press, 1998), ch 2 at 112, 129. This interdisciplinary study combines anthropology, linguistics, social psychology, and law. For further reading on the comparative success of rule-oriented and fact-oriented claimants as opposed to relation-oriented claimants in US small claims courts and how language structures replicate existing hierarchies, see John M Conley \& William M O'Barr, Rules versus Relationships: The Ethnography of Legal Discourse (Chicago: University of Chicago Press, 1990) (particularly at 58-59). See also generally Elizabeth Mertz, The Language of Law School: Learning to “Think Like a Lawyer” (New York: Oxford University Press, 2007).

19 Antoine Garapon, Bien juger: essai sur le rituel judiciaire (Paris: Odile Jacob, 1997) at 146. 
signs of prejudice toward and among the parties, thereby enhancing impartiality and procedural neutrality. What we cannot ask of rituals, however, is to play the role of broader institutions that can shape and reshape social constructs and perceptions held by the parties or the decision makers.

\section{Rituals as a Shield against Violence}

Rituals may help to prevent recourse to violence. For instance, despite great diversity in judicial rituals and forms of the interrogation process across communities, witness examination usually involves a third-party neutral tasked with clarifying the "facts" or the "evidence." Brenda Danet suggests that involving a third party is more effective than other potential configurations for interrogation, such as the use of open-ended narrative discourses, at preventing disputes from turning into violent outbursts. ${ }^{20}$ Two caveats, however, are necessary. First, in legal cultures such as those of China and Japan, anthropologists observe a predominant notion that resorting to law, codifications, and judges in order to solve conflicts is a sign of failure and is unworthy of civilized people. ${ }^{21}$ Individuals are expected to pursue their social life without disputes, according to well-established norms of behaviour geared toward maintaining harmony.

Second, the role of third-party neutrals in circumventing violence is heavily dependent on a restrictive definition of violence and a positive view of bureaucracy, as legal bureaucracy itself may be a form of violence. ${ }^{22}$ Legal bureaucracy, its courts, and its training of legal professionals such as lawyers and judges, are mostly the product of European colonial enterprises. At the time of their independence, a number of new states were involved in creating their own legal systems while also dealing with existing social practices and judicial rituals in the territories that comprised these new states. For instance, the palabre, a process involving lengthy, open-ended storytelling, is still used today as a dispute resolution mechanism in sub-Saharan Africa. ${ }^{23}$ Rituals such as the palabre are thus capable of integration within the legal parameters of state justice. In other cases, however, legal bureaucracy may be unable to carry out this integration without giving rise to contradictions. Courts in Cameroon and South Africa, while enforcing

20 Brenda Danet, "Language in the Legal Process" (1980) 14:3 Law \& Soc'y Rev 445 at 516. See also Leopold Pospisil, Anthropology of Law: A Comparative Theory (New York: Harper \& Row, 1971) at 236.

21 Norbert Rouland, Introduction historique au droit (Paris: Presses universitaires de France, 1998) at 43.

22 In the Canadian context, the concept of legal bureaucracy as violence is particularly clear in the context of Aboriginal people's experiences of the justice system. As expressed, for example, in the Report of the Aboriginal Justice Inquiry of Manitoba, "[f]or Aboriginal people, the essential problem is that the Canadian system of justice is an imposed and foreign system. In order for a society to accept a justice system as part of its life and its community, it must see the system and experience it as being a positive influence working for that society. Aboriginal people do not." Aboriginal Justice Implementation Commission, Report of the Aboriginal Justice Inquiry of Manitoba (November 1999) at ch 7, online: Manitoba Government <http://www.ajic.mb.ca/volumel/chapter7.html $>$. The report's recommendations, including the establishment of Aboriginal justice systems reflecting traditions and cultures of Aboriginal communities, make clear the potential for a lack of meaningful participation within the existing justice system due to its failure to adequately reflect Aboriginal values.

23 Étienne Le Roy, Les Africains et l'institution de la justice: entre mimétismes et métissages (Paris: Dalloz, 2004). 
laws against witchcraft, have also had to recognize sorcerers and witches as eligible witnesses. ${ }^{24}$

\section{Rituals Are Erroneously Perceived as Irrational}

One reason the literature has largely overlooked judicial rituals may be a misconception that rituals are irrational. For early twentieth-century American realists, rituals obstructed sound empirical, rational, legal thought. Some considered, for example, that rules of procedure were nothing but "magic solving words," "word ritual," or a "legal myth" concealing the influence of personal preferences and ideology on decision making. ${ }^{25}$ In countering this notion that magic and rituals are irrational, Allen relies on the works of modern anthropologists to argue that these facets of dispute resolution may support both the legitimacy and efficiency of law. ${ }^{26}$

Rituals may seem absurd from afar yet be meaningful to participants - for reasons including socio-cultural considerations. This "contextual rationality" of rituals, as opposed to lottery-like adjudicating mechanisms, for example, such as the heads-or-tails game, should be further explored. In addition, some legal anthropologists have attributed the historical resurgence of the ritual of the ordeal to economic shortages in regions where it had previously disappeared. ${ }^{27}$ This raises the question of rituals' efficacy as a second-best option where due process requirements are disproportionate compared to available resources or the stakes of a dispute. In particular, can rituals produce unjust yet enforceable, acceptable, or legitimate results? If so, from where do such rituals draw legitimacy? Finally, beyond economic constraints, contextualizing certain seemingly abhorrent rituals may clarify notions of fairness and efficiency that have so far been overlooked.

\section{B. Judicial Architecture}

In addition to rituals, judicial architecture serves to communicate symbols of justice. Is it possible to think about justice devoid of any material representation? Eliana Patrícia Branco argues that "judicial architecture must be construed as an integral part of legal discourse." ${ }^{28}$ For her, architecture fosters intellectual access to justice by materializing abstract notions. Architecture thus expresses norms contained in the law. ${ }^{29}$ Indeed, in France, Arnaud Sompairac has posited three guiding principles for courthouse design: monumentality, transparency, and

24 Peter Geschiere, "Witchcraft and the Limits of the Law: Cameroon and South Africa" in Jean Comaroff \& John L Comaroff, eds, Law and Disorder in the Postcolony (Chicago: University of Chicago Press, 2006) 219.

25 Jessie Allen, "A Theory of Adjudication: Law as Magic" (2008) 41:4 Suffolk UL Rev 773 at 773-774, 796802 .

26 Ibid at $775,805 \mathrm{ff}$.

27 See generally transcripts of the pluri-disciplinary symposium Centre d'histoire et d'anthropologie du droit, Paris-Ouest Nanterre, Puissances de la nature: Justices de l'invisible: du maléfice à l'ordalie, de la magie à sa sanction (2 December 2010).

28 Eliana Patrícia Branco, "Justice et architecture: la relation entre accès au droit et architecture judiciaire" in Guillaume Protière, ed, Espaces du droit et droits des espaces (Paris: Harmattan, 2009) 49 at 52 [translated by authors].

29 And vice versa: René Cassin considered that the United Nations charter ought to be structured according to the model of a Greek temple's frontispiece. See Mary Ann Glendon A World Made New: Eleanor Roosevelt and the Universal Declaration of Human Rights (New York: Random House, 2001), ch 10. 
theatricality. ${ }^{30}$

Rituals and judicial architecture are closely linked to the complex system of values that they embed. In line with Sompairac's principles, judicial architecture traditionally inspired a sense of authority and drama by using vertical features borrowed from sacred architecture. Rituals were consistent with this theatrical setting. Recent designs, however, have tended to represent justice by way of transcendental horizontality, symbolizing democracy's immanence. Transparency is also more valued than monumentality. Consequently, judicial architecture is blurring the lines of the complex system of values that characterize justice, and certain discrepancies appear between judicial rituals and their architectural setting. For David Marrani, rituals should be taken into account prior to designing a courthouse. ${ }^{31}$ The aesthetic dimensions of the courthouse, therefore, far from being apolitical and incidental, may ensure the strength and force of an institutional order. ${ }^{32}$ David Tait remarks that Australian courts, and other public buildings, display authority and sovereignty. ${ }^{33}$ Josiane Boulad-Ayoub posits that Quebec's architecturally Anglo-Saxon courts, as cultural and ideological institutions, and notwithstanding strong ties to the civilian legal tradition, canvass cultural and political frameworks for the public sphere. ${ }^{34}$

Regarding the relationship between judicial architecture and civil procedure, the few critical perspectives offered so far help to define questions requiring further study. Are symbols meant to represent law as it is or as it ought to be? To whom are symbols addressed? How well do symbols reach their targeted audience? Is there more to judicial architecture than mere symbolism?

A preliminary enquiry is whether judicial architecture can convey procedural values accurately or even at all. On the latter point, Boulad-Ayoud associates the symbols in older Montreal courthouses with a bourgeois culture that only an exclusive audience can decipher. For instance, laymen may perceive the Quebec Court of Appeal as an impressive "thingamajig" inspiring respect, but no more. ${ }^{35}$ In contrast, Resnik and Dennis Curtis provide a value-laden account of judicial architecture, courthouse design, and the use of symbols and rituals. They note, however, the ambivalence of symbols of justice such as the female figure, the blindfold, and the use of glass material. While, blindfolds or clear-eyed figures may symbolize rationality, neutrality, incorruptibility, or even perception and understanding, competing interpretations may

30 Caroline Lecourtois, “'Espace de conception' d'architectures judiciaires: les nouveaux palais de justice (Caen, Melun, Nantes, Grenoble et Pontoise)" (2010) 4 Diagonale Phi 31 at 37-38, citing Arnaud Sompairac, Conception architecturale des palais de justice (Paris: Ministère de la justice, 1992).

31 David Marrani quoted in Philippe Samson, "Vers une cyberjustice: l'architecture juridique en changement" (2012) 44 Journal du Barreau du Québec 12.

32 Piyel Haldar, "In and Out of Court: On Topographies of Law and the Architecture of Court Buildings" (1994) 7:2 Int'1 J Sem L 185. See also David Evans, "Theatre of Deferral: The Image of the Law and the Architecture of the Inns of Court" (1999) 10:1 Law \& Critique 1; Jeffrey S Wolfe, "Toward a Unified Theory of Courtroom Design Criteria: The Effect of Courtroom Design on Adversarial Interaction" (1995) 18:3 Am J Trial Advoc 593.

33 David Tait, "Popular Sovereignty and the Justice Process: Towards a Contemporary Methodology for Observing Courtroom Rituals" (2001) 4 Contemporary Justice Rev 201 at 202.

34 Josiane Boulad-Ayoub, "Le palais de justice de Montréal: du temple à la tour" in Nycole Paquin, ed, Les signes de la justice et la loi dans les arts (Quebec: Presses de l’Université Laval, 2008) 51.

35 Ibid. 
suggest blindness to truth, ignorance, or a justice that is easily misled or vulnerable to temptation or corruption. The blindfold - like John Rawls's procedural veil of ignorance ${ }^{36}$ - has been attacked for presenting an illusion of fair treatment and neutrality, bestowing undeserved legitimacy. Such critiques thus question "which facets of human experience law ought to take into account" or "what aspects of identity are relevant to judging." 37 Practically, Resnik and Curtis conclude that courthouses' use of statues of dead white males and naked women is inconsistent with claims of legitimacy. ${ }^{38}$ In a similar vein, using glass to reify transparency divides up spaces, creating exposure and barriers, as well as a misleading or inaccurate picture of the workings of the law, especially regarding the legitimacy-related values of openness, public accessibility, and participation. ${ }^{39}$

These values relating to inclusion of the public, a key part of popular narratives in UK and American legal reform, may, interestingly, stand in contrast to the symbol of scales used in judicial architecture. To Resnik and Curtis, the image of scales reflects the decline of the legitimizing function of the divine and the all-powerful ruler. Scales locate impartiality not in the person of a decision maker but, rather, in the process of hearing the other side (audi alteram partem $){ }^{40}$ In the context of the vanishing trial phenomenon, this secularization process may reduce the role of judges to legitimizing decisions made by others in private: creating potential for an exclusion of the public at odds with the value of access to justice. This exclusion occurs both through courtroom and courthouse segregation and through the movement of adjudication out of public spaces and physical courtrooms, using ADR as well as practices such as plea bargaining. In civil matters, there are numerous procedural rules that abruptly end a dispute and take it off the docket. In this respect, the multi-door approach to justice has not only multiple entrances but also multiple exits. This critique highlights the paradoxical "importance of the public for the legitimacy of modern legal institutions ... and the continued need for the public to be participants and critical observers of adjudication, undermined by the loss of public connection" in the past decades. ${ }^{41}$

Rituals and architecture play a key role in conveying values that underlie and legitimize the civil justice system to participants in an intellectually accessible manner. The value of architecture and ritual within the public adjudication system, in terms of helping it provide the stability that individuals rely on in order to exercise their agency, must be kept in mind in

36 Kathy Mack, Book Review of Legal Architecture: Justice, Due Process and the Place of Law by Linda Mulcahy, Representing Justice: Invention, Controversy, and Rights in City-States and Democratic Courtrooms by Judith Resnik \& Dennis Curtis (2012) 39:2 JL \& Soc'y 317 at 321; John Rawls, A Theory of Justice (Cambridge, MA: Belknap Press, 1971). See also Charles Taylor, "The Politics of Recognition" in Amy Gutmann, ed, Multiculturalism: Examining the Politics of Recognition (Princeton, NJ: Princeton University Press, 1994) 21.

37 Resnik \& Curtis, supra note 7 at 97; Mack, ibid at 321.

38 Resnik \& Curtis, supra note 7 at 106.

39 Linda Mulcahy, Legal Architecture: Justice, Due Process and the Place of Law (Abingdon, UK: Routledge, 2011) at 153.

$40 \quad$ Resnik \& Curtis, supra note 7 at $\mathrm{xv}, \mathrm{n} 4$.

41 Mack, supra note 36 at 322. For a parallel with the emergence of the state as a form of political organization and the use of sovereignty as a discourse legitimizing power, see Michel Foucault, Il faut défendre la Société: Cours au Collège du France, Cours du 14 janvier 1976 (Paris: Seuil/Gallimard, 1997) at 22-36. 
discourse on civil justice reform. At the very least, reforms should ensure that the benefits of procedures that reinforce the legitimacy of legal institutions are considered. If the role of public institutions in administering justice is to change or be reduced in favour of private justice solutions, alternative means of reinforcing the legitimacy of adjudication, and the guarantee of certainty provided by existing schemes, will be necessary.

\section{The Arbitration Puzzle}

We saw above the link between adjudication as a form of public service, the legitimacy of adjudicative institutions, and the strong presence of judicial rituals and architecture in dispute resolution models. Yet, must all dispute resolution processes be ritualized? In addressing this point by turning to what we label the "arbitration puzzle," we extend our focus beyond the court system to other forms of dispute resolution processes designed for conflicts that survive negotiation and require intervention by a third-party neutral.

Judicial rituals arguably respond to certain fundamental needs in terms of fairness and equity, reliability, and neutrality of the judicial process. Yet active participation - and the feeling that one has had the opportunity to make one's case, has been heard, and has been treated with respect and dignity - is a major factor in a party's assessment of the fairness and legitimacy of a dispute resolution process. In judicial trials, due process ensures that the parties' arguments are heard, though the parties may not feel they are actively controlling anything. Arbitration arguably calls for a more active form of participation and a more significant exercise of autonomy. The parties appoint the arbitrators who will decide their dispute, and they may choose the applicable rules of procedure. ${ }^{42}$

Arbitration also differs from judicial trials with regard to the role of ritual within the proceedings. In commercial arbitration, for instance, the judicial robes, carefully conceived court architecture, and obligation to rise when the judge enters, which are all characteristic of judicial trials, are replaced respectively by a business dress code, a meeting space that is typically a conference room in a hotel or other anonymous facility, ${ }^{43}$ and sharing coffee. ${ }^{44}$ While arbitration exists in many forms beyond this commercial context - including labour arbitration, family law arbitration, and arbitration under religious law, each of which will draw upon ritual in different ways - and shares many similarities with judicial trials (for example, questioning by a third-party neutral and deference shown to that third-party neutral), arbitration generally displays a simpler form of ritual than that seen in trial adjudication.

Returning to the definition of ritual at the beginning of Part II of this article, a distinction can

42 It should be noted that, despite the potential for parties to determine their own rules of procedure in arbitration, this ability to determine procedure can be limited in practice. A notable example relates to the consumer context since many jurisdictions permit cases to proceed to arbitration on the basis of standard-form contracts, the terms of which were drafted with no input from the consumer. For an illustration of this phenomenon in the United States, see AT\&T Mobility v Concepcion, 531 US 321 (2011).

43 Mulcahy has notably qualified hotel rooms as familiar places that are relatively anonymous and neutral compared to more imposing courthouses. Mulcahy, supra note 39 at 173-174.

44 A standard room layout and specific sitting arrangement, as well as the fact that no one stands up to speak, were also identified as arbitration hearing rituals. Emmanuel Gaillard, "Sociology of International Arbitration" (2015) 31 Arbitration International 1. 
clearly be drawn between arbitration and judicial trials. Arbitration's private nature and emphasis on individual choice may prevent parties from perceiving their arbitration as part of a systemwide pattern of repeated behaviour, compelling certain conduct on their part and having consequences for third parties. For instance, even for parties who return repeatedly to arbitration in the commercial context, the consensual, contract-based jurisdiction of arbitrators, and the ability to pick and choose by contract the rules by which each arbitration will be conducted (which may include the ability to opt in and out of certain procedural rituals), may weaken the perceived normative effect of past behaviours in distinct instances of arbitration, even if such behaviours are similar in practice. ${ }^{45}$ Arbitration's increasing success as a dispute resolution mechanism indicates that at least some disputes can be resolved with very minimal ritual.

We thus identify two poles contributing to the binding character of a dispute resolution: ritual, typically exalted in judicial trials, and participation, which is enhanced in less formal settings. Our hypothesis is that ritual and active participation are two potentially, but not necessarily, mutually exclusive dimensions of procedural fairness. We have discussed, above, the role of ritual in legitimizing public adjudication as well as the need for private justice, which generally relies less on the notion of ritual, to create the same stability in the law in order to be perceived as legitimate. One way in which the ritual aspects of civil procedure discussed earlier do so is by drawing the parties into the proceedings. As seen above, rituals serve to impress upon the parties the authority and power of the court and decision maker, the correct means of interacting nonviolently with the opposing party, and the rationality of the system of dispute resolution. Rituals integrate the parties into the dispute resolution process, by indicating their place in the system relative to other participants as well as the correct ways of engaging with these other participants. In this sense, rituals, or at least certain aspects of rituals, serve to define parties' roles and ability to participate within the adjudication - usually only a limited and passive role ${ }^{46}$ - and this effort to situate the parties within the decision-making process supports its overall legitimacy. We thus posit that, where the role of ritual is decreased in private justice, it is this notion of participation in the proceedings - this time, more active participation that positions the parties more clearly at the centre of the process - that can step in to assist in legitimizing the dispute resolution. Accordingly, a less-ritualized proceeding may still be perceived as legitimate if it is based on a more active form of party participation. This hypothesis, however, raises the issue of the "arbitration" puzzle: a binding decision resulting from a minimally ritualized process and

45 In comparing the normative effect of behaviour in arbitration and trial adjudication, it is interesting to note the fact that Western popular culture, including film and television, has inundated individuals with images of what judicial trials mean, how actors within them behave, and, particularly, the legitimacy of the adversary system. See eg Michael Asimow, "Popular Culture and the Adversary System" (2007) 40 Loyola LA L Rev 653. While, on the one hand, this phenomenon may lead participants to ascribe less normative value to arbitration as it occurs outside the traditional court setting, on the other hand, it may also reinforce the legitimacy of the adversarial aspects of arbitration or act as a pressure within arbitration toward more court-like forms of procedure.

46 Problems associated with this limited role for parties within court systems have led to numerous civil procedure reforms in recent years - from plain language movements to online dispute resolution to the incorporation of aspects of traditional aboriginal justice within state court systems - which aim to increase parties' inclusion in and understanding of the proceedings. 
participation that, as will be discussed below, is limited in that it does not extend to controlling the content of the outcome.

Why the "arbitration" puzzle? Why not the "ADR" puzzle? Mediation, for instance, is hardly ritualized compared to trials; the fact that mediators have highly structured routines to foster cooperation does not entail that the parties perceive the session as ritualized. And despite minimal ritual, the outcomes of both arbitration and (successful) mediation are binding. The difference is that parties to an arbitration agree to uphold the arbitrator's decision before knowing its content, whereas parties to a mediation uphold the outcome, by having a judge homologate their settlement as needed, only after having agreed upon its content. In other words, the binding character of a mediation settlement may be explained, to the extent that parties know the substance of the settlement before agreeing to its binding character, by the parties' satisfaction with the result rather than with the legitimacy of the process itself. On the contrary, the binding character of arbitration awards is known ex ante. There lies the puzzle: arbitration typically displays both a reduced ritual and, ultimately, an outcome that the parties cannot control, and it is neither ritual, nor participation, nor party satisfaction that explains the bindingness of the arbitration.

We cannot justify arbitration's binding nature based on the fact that arbitrators articulate the norms applicable to a case. Contrary to public adjudication, arbitration is not generally meant to create a public space fostering social cohesion or to produce, at least in its commercial instantiation, case law for the benefit of society as a whole. While for judges, wearing robes and carrying out other formalities provide a reminder that society entrusts them with the power to exercise public authority, for arbitrators, the mere consent of the parties is enough to confer all the legitimacy they need to fulfill their function.

As Thurman Arnold wrote decades ago,

[t]he ceremonial trial never is, or can be, an efficient method of settling disputes. Of course efficiency is one of its ideals, but there are others equally important which must also be dramatized. Therefore, if we want real speed, or efficiency - in other words, if results are more important than the moral lessons which are to be taught by the process - we move the settlement of the dispute into a less symbolic atmosphere. We find this atmosphere in what we call administrative tribunals. Yet in a climate of opinion which demands the comforting belief that there is a "rule of law," the administrative tribunals never quite satisfy us, and the ceremonial trial continues as a method of resolving all disputes concerning which philosophical argument is possible. ${ }^{47}$

The symbolic, ritual, ceremonial aspects of a hearing thus appear linked to the more or less crucial need to legitimize the outcome of the process. One working hypothesis is that this link is established by the importance of the decision in the eyes of the public (that is, its impact on third

47 Thurman W Arnold, The Symbols of Government (New York: Harcourt, Brace \& World, 1935) at 133. 
parties or on society more generally), notably through practices or the doctrine of persuasive or binding precedent. Today, decades after Arnold's insight, the link between rituals, the legitimacy of a dispute resolution process, and the importance of a particular dispute in the eyes of the public is echoed in the notion of inarbitrability. Inarbitrability, an exception to the increasingly accepted principle that any dispute may be resolved by arbitration, rests on the notion that arbitrators should not decide at least some issues engaging public order.

Before we conclude on the arbitration puzzle, it is worth mentioning that some issues of a very public nature are dealt with through processes involving less formalized rituals, including truth and reconciliation commissions, investigative commissions, or public consultations. In these cases, legitimacy is not gained solely through powerful rituals but also, perhaps primarily, by inclusion of all concerned parties. ${ }^{48}$ The means and extent of inclusion may form part of a broader ritual, such as when participants are invited to raise their points one after the other. The end result of such processes, however, may or may not produce binding consequences. This is an important area for further research on civil procedure and one that calls for robust interdisciplinary analysis. Overall, we can see that there are no magical formulas to explain why a particular dispute resolution mechanism is adequate. However, we can contrast rituals with expediency, and the private with the public aspects of adjudication, as well as identify participation as a key factor in ADR mechanisms.

\section{THE INDETERMINACY OF LEGAL NORMS}

The arbitration puzzle identified above has led us to remark that arbitration awards, at least in the commercial setting, are not meant to clarify the law for the benefit of society. ${ }^{49}$ Arbitration awards are often confidential, and the doctrine of precedent still plays but a limited role in the arbitral community. However, the articulation of legal norms is one of the public adjudicative system's core functions and sources of legitimacy. Indeed, similarly to the legitimizing function of judicial rituals and architecture, the articulation of legal norms serves to stabilize expectations about the law and is a characteristic associated with public adjudication. While, in the context of rituals and architecture, this stabilization may occur through the communication of values that underlie and legitimize the judicial system in an intellectually accessible way, the formal articulation of legal norms ensures stability in the law by requiring that like cases be treated alike, with higher courts refining the law, while lower courts work to adequately deal with the volume of disputes. The ability to rely on stable expectations about the law permits individuals to exercise their autonomy and be treated with dignity under the law.

48 On the intricacies of ensuring meaningful inclusion of marginalized populations within the proceedings of commissions of inquiry, see eg Darcie Bennet et al, Blueprint for an Inquiry: Learning from the Failures of the Missing Women Commission of Inquiry (BC Civil Liberties Association, West Coast Women's Legal Education and Action Fund, Pivot Legal Society, 2012).

49 It must be kept in mind that public law dimension of arbitration may be more apparent in other contexts, for example, labour arbitration takes place within a public law statutory framework, and arbitration in the religious context deals with the interpretation of community norms. We focus on commercial arbitration in order to have the opportunity to consider the bases for adjudicative legitimacy in the absence of a clear need to articulate formal norms for the public benefit. 
In the discussion of the value of the formal articulation of legal norms, we begin with an examination of situations of legal indeterminacy, where it falls to an adjudication process to articulate a clear norm for the benefit of the public. This aspect of adjudication is largely ignored in the literature on civil procedure, and, more broadly, on civil justice, which tends to take the law applied by courts and tribunals as a fixed term. We first briefly recall the theoretical debate around legal norms' inherent indeterminacy. We then observe a paradox similar to that of the arbitration puzzle, regarding the binding character of erroneous judicial decisions. Finally, we qualify the paradox by weighing the benefits of articulating legal norms through the judicial process.

\section{A. Theoretical Shortcomings}

The indeterminacy of legal norms - sometimes called the "vagueness" theory ${ }^{50}$ - has largely been deemed peripheral, marginal, or irrelevant by legal positivists, while legal realists have often focused on human biases in decision making, negating the relevance of indeterminacy altogether. The legitimacy of judicial decisions is often explained in terms of their legality: the notion that judges apply the law more than they create it. Legitimate decisions are made under the total or partial constraint of the law. ${ }^{51}$ Positivists argue that judges may legitimately use their discretionary powers to legislate in the "interstices of the law" 52 or within the "penumbra" occurring in "hard cases.",53

In contrast, the interpretive or adjudicative approach denies that such gap-filling powers are discretionary, let alone abusive. ${ }^{54}$ In this view, law is a semi-open system. In addition to legal norms, basic principles and core values of justice present in society constrain judges in their decision making. Judges base their decisions on written law and precedent, but they may be required to use their discretionary power and interpret moral principles relating to justice and equity. ${ }^{55}$ Interpretivism departs from jusnaturalism's traditional focus on the relation between

50 Roy Sorensen, "Vagueness" in Edward N Zalta, ed, The Stanford Encyclopedia of Philosophy (Winter 2013).

51 Certain authors distinguish between the legitimacy of the judicial institutions we refer to here and notions of legitimacy developed by sociologists including Max Weber. See Ken Kress, "Legal Indeterminacy" (1989) 77 Cal L Rev 283 at 285.

52 Benjamin N Cardozo, The Nature of the Judicial Process (New Haven, CT: Yale University Press, 1921) at 102-105, 113-115. See also Southern Pacific Co v Jensen, 244 US 205 (1917) (Holmes, J, dissenting): "I recognize without hesitation that judges do and must legislate, but they can do so only interstitially; they are confined from molar to molecular motions" (at 221).

53 HLA Hart, "Positivism and the Separation of Law and Morals" (1958) 71 Harv L Rev 593 at 606-607.

54 Stephen R Perry, "Judicial Obligation, Precedent and the Common Law" (1987) 7:2 Oxford J Legal Stud 215 at 216.

55 Supporters of this view include Ronald Dworkin, Taking Rights Seriously (Cambridge, MA: Harvard University Press, 1978), ch 2-4; George P Fletcher, "Two Modes of Legal Thought" (1981) 90 Yale LJ 970; George P Fletcher, "Punishment and Compensation" (1980) 14 Creighton L Rev 691; Charles Fried, "The Laws of Change: The Cunning of Reason in Moral and Legal History" (1980) 9 J Legal Stud 335; Lon L Fuller, "Reason and Fiat in Case Law" (1946) 59 Harv L Rev 376; Lon L Fuller, "The Forms and Limits of Adjudication" (1978) 92 Harv L Rev 353; Ernest J Weinrib, “Toward a Moral Theory of Negligence Law" (1983) 2 Law \& Phil 37. 
law and morals and turns toward the pursuit of justice in the context of formal dispute resolution. Form, along with procedure, plays a decisive role in legitimizing a judicial decision.

For positivists, however, legitimacy stems from the fact that the law is "posited" by social acts, beliefs, dispositions, and attitudes present in the community to which the law applies. ${ }^{56}$ Positive law is usually statutory, jurisprudential, and customary. Beyond these sources, judges are considered to use their discretionary power. The law, in theory, provides sufficiently determined legal norms for judges to compare, analyze, and evaluate parties' behaviours. One advantage of this position is that the legality or validity of a norm is well defined and the validity criterion is overall internal to the law. However, the issue of legal norms' indeterminacy, reduced to regulating how judges use discretionary power, becomes peripheral. This position obviates important issues including the dynamic interactions between facts and norms, the capacity for legal norms to comprehend moral claims, and the acceptable level of indeterminacy for any given legal norm. In sum, the role of the judge in shaping the law is heavily underplayed. While interpretivists recognize this role, they tend to overlook how the process of articulating legal norms is instrumental in legitimizing the judicial system.

\section{B. Compromising Truth}

Many procedural rules promote accuracy: the discovery process, cautious proceedings that include cross-examination, neutral judges and juries, rules of evidence, and representation by counsel. Appeals are also meant to prevent mistakes. Even statutes of limitations have been interpreted as promoting more accurate decisions. ${ }^{57}$

The accuracy of decisions ("ascertaining the real truth" based on the merits of the case) has been identified as a fundamental value of procedural justice, ${ }^{58}$ although, as one critic notes, a judicial system geared solely toward truth is utopian and fails to consider implementation costs. ${ }^{59}$ If one recalls the opposition between formal and substantive justice, a broader argument can be made that values of justice, including truth, are made manifest only inasmuch as they are respected in practice. Where most criminal cases are resolved through plea bargaining - or where public defenders and court-appointed counsel, who represent a majority of criminal defendants in the United States ${ }^{60}$ are so chronically and drastically underfunded as to call into question the vigour and effectiveness of the advocacy they can provide - formal guarantees of accurate decision making are compromised. ${ }^{61}$

56 See eg HLA Hart, The Concept of Law (Oxford: Oxford University Press, 1961); HLA Hart, Essays on Bentham: Jurisprudence and Political Philosophy (Oxford: Oxford University Press, 1982) ch 6, 10; Joseph Raz, Practical Reason and Norms (w3 ww3London, UK: Hutchison, 1975) ch 4-5; Joseph Raz, The Authority of Law: Essays on Law and Morality (Oxford: Oxford University Press, 1979).

57 Tyler T Ochoa \& Andrew J Wistrich, "The Puzzling Purposes of Statutes of Limitation" (1997) 28 Pacific LJ 453 at $471-482$.

58 Lawrence B Solum, "Procedural Justice" (2004) 78 S Cal L Rev 181 at 244.

59 Laurens Walker, "Avoiding Surprise from Federal Civil Rule Making: The Role of Economic Analysis" (1994) 23:1 J Legal S 569 at 575-576, 582.

60 William J Stuntz, "Plea Bargaining and Criminal Law's Disappearing Shadow" (2004) 117:8 Harv L Rev 2548.

61 David Alan Sklansky, “Anti-Inquisitorialism” (2009) 122:6 Harv L Rev 1634. 
We collectively accept that truth may be compromised because, beyond truthfulness, there are usually reasons to value that a decision has been rendered per se. The standards for the review of a decision (for example, material mistake and abuse of judicial discretion), while preventing some factual mistakes, also validate erroneous decisions. In US law, mistakes of fact will not be corrected unless the relevant findings are "clearly erroneous" in the sense of being unsupported by evidence. ${ }^{62}$ In Canadian law, mistakes of fact in civil matters are acceptable, if not so "palpable and overriding" that a different decision ought to have been rendered. ${ }^{63}$ The res judicata doctrine also favours the finality of decisions. It is a notion of public order that legal suits must come to an end at some point, even where the court made a decision without an exhaustive understanding of the facts. Finally, the stare decisis doctrine, as well as notions of persuasive precedent or jurisprudence constante, suggests that case law and jurisprudence are a public good by which to stabilize formulations and interpretations of the law while accounting for unforeseeable social or technological developments. The goal is to pursue not absolute "capital $T$ " Truth but, rather, a compromise, sometimes referred to as "small $t$ " truth, with other important values such as efficiency or equality before the law - although only insofar as the compromise does not have material consequences for outcomes. ${ }^{64}$ When compromising on truth, the law is not solely a dispute resolution system. Dispute resolution is rather an intermediary goal, a proxy for stabilizing human expectations in a changing world and thus increasing agency - by allowing individuals to plan their lives - in the name of human dignity.

In the Principles of the Civil Code, Jeremy Bentham wrote:

The disposition to look forward, which has so marked an influence upon the condition of man, may be called expectation - expectation of the future. It is by means of this we are enabled to form a general plan of conduct; it is by means of this, that the successive moments which compose the duration of life are not like insulated and independent points, but become parts of a continuous whole. Expectation is a chain which unites our present and our future existence, and passes beyond ourselves to the generations which follow us. The sensibility of the individual is prolonged through all the links of this chain.

62 United States v US Gypsum Co, 333 US 364 at 395 (1948).

63 Housen v Nikolaisen, 2002 SCC 33, [2002] 2 SCR 235. The Court distinguishes between standards of review for pure questions of law, questions of mixed law and fact, and pure questions of fact in a way that is instrumental rather than ontological. Mixed questions of law and fact are effectively assimilated to pure questions of law when there is a clear mistake in the characterization of the applicable standard of law. This is in line with appellate courts' "primary role" of delineating and refining legal rules, and of ensuring their universal application (at para 9), allowing intervention where there is a public interest in resolving a question of law by generating precedent and stabilizing the law.

64 This criterion appears clearly in the standards of review of judicial decisions, where mistake of fact must be "palpable and overriding" (ibid at para 1), and of arbitral awards. Fabien Gélinas, "Le contrôle de la sentence pour défaut de conformité de la procédure aux règles applicables: quelques questions" in Sylvette Guillemard, ed, Mélanges en l'honneur du professeur Alain Prujiner (Cowansville, QB: Yvon Blais, 2011). 
The principle of security comprehends the maintenance of all these hopes; it directs that events, inasmuch as they are dependent upon the laws, should be conformed to the expectations to which the laws have given birth. "Security," or the management of human expectations, is thus at the heart of the liberal project, seen as a precondition for the exercise of individual liberty and as the most fundamental element of the rule of law.

\section{Stability as Normative Accuracy}

Values of justice have been identified in numerous ways, but their dynamic interactions remain difficult to assess. One example of a dynamic interaction is the following: procedural rules providing for more efficient decision making are acceptable only if the resulting, particular decisions would not have been different had they been based solely on the values of accuracy and stability. Procedural arrangements can be flexible if they achieve an acceptable balance between substantive justice (accuracy) and formal justice (stability). In other words, in terms of the distinction between factual accuracy - or substantive justice based on the merits of each case - and normative accuracy - or formal justice based on accurate norms - reducing truth to factual accuracy overlooks the all-important value of normative accuracy.

In considering the binding character of factually inaccurate decisions, the principle of audi alteram partem and its role in safeguarding the parties' dignity must be considered. While procedural norms allowing each party to be heard are intertwined with the value of accuracy the unwinding of several versions of the facts of a case - their ultimate goal is to foster equal dignity of each party, and, thus, they do not guarantee that a court's decision will be accurate. A procedure formally respectful of the parties' due process rights may lead to factually inaccurate decisions due to poor quality of evidence, rules of confidentiality, witness credibility, strategic interests, or simply a lack of resources and time. We thus need something more than mere respect for the dignity of the parties to explain the binding character of inaccurate decisions, especially toward third parties.

What is it, then, that gives rise to the notion that a judicial decision is final and binding, even if one or more parties believe or know that the decision is factually or normatively erroneous? It cannot be the decision's accuracy since, by definition in this case, the decision is not accurate. The parties' satisfaction with the trial and its outcome may explain the legitimacy of erroneous decisions. However, social psychologist Tom R. Tyler has demonstrated that the parties' satisfaction has little to no correlation with the favourable outcome of the dispute resolution process. ${ }^{66}$ In addition, the parties' satisfaction is consistent with the res judicata doctrine but not with the precedential force of the decision. A theory of procedural justice concerned only with the parties' satisfaction would not be able to produce a stable, public system of law or justify the effect of judgments on third parties or why we should have any instances of public adjudication

65 See Jeremy Bentham, Principles of the Civil Code: Principles of Penal Law (London: W Tait, 1843), ch 7.

66 Tyler, supra note 6. It should be noted that Tyler has refined and developed his concept of participation through the years. While his early work focused on the degree to which individuals felt heard and validated, rather than their role in designing procedures, Tyler's 2006 Why People Obey the Law (supra note 6) also accounts for a political dimension of participation. In the latter, Tyler conceptualizes parties as citizens whose role in proceedings amounts to political participation and, by extension, institutional design. 
at all. Furthermore, if parties are satisfied by conditions other than accurate decision making, one may wonder why disputes are not solved by negotiation, private adjudication - or even a coin flip. Finally, a party may also not be satisfied with the accuracy of a decision or may be satisfied not because the decision is accurate but, rather, because he or she cannot afford a more accurate decision.

Lawrence Solum suggests that the parties' mere participation in the dispute resolution process generates enough legitimacy to explain why a decision constitutes binding precedent where neither accuracy nor the parties' satisfaction accounts for the binding character of the decision. ${ }^{67}$ However, this explanation seems to indicate that some justice is achieved even where the decision-making process is ill-informed or inaccurate or when the outcome is insufficiently based on the merits of the case.

We should not, however, relinquish the attempt to explain the binding character of a decision by reference to accuracy, as Solum's participation-based explanation suggests. Giving up on accuracy would undermine the very possibility of a sound liberal justification for adjudication. It would create the possibility that, even if erroneous decisions are quantitatively or qualitatively marginal, their binding character may rest on arbitrary, if not authoritarian, considerations. ${ }^{68}$ The practical importance of this issue may be subject to debate, but we can spare ourselves this debate altogether if we solve the issue in principle.

Giving greater consideration to the process of articulating legal norms may make more space for the standard of accuracy. Indeed, accuracy may be construed as either factual or normative and even, preferably, as a normative and factual compound. In this respect, it seems more convincing to say that the binding character of an erroneous decision should stem from the intrinsic value of articulating judicial norms. The benefit of a clearer norm in the future trumps a potentially mistaken understanding of the facts. That there may be some substantial injustice in the process could be viewed as the parties' contribution to improving the quality of the law and the judicial system they are using, which judges may take into account, for example, by making damages proportional to the degree of inconsistency or ambiguity encountered in the law. This interpretation also provides an additional and perhaps more compelling justification for the traditional subjection of mistakes of law to a broader scope of review than mistakes of fact.

67 Solum, supra note 58 at 273-274.

68 In Schmitt's view, a decision is binding merely because it has been rendered by an organ of the state (ie, a particular jurisdiction, duly constituted and with official powers to make such a decision) and is thus disconnected from notions of accuracy. For him, any constitution is based on some form of violence or authority, and this violence is replicated in the decision, which is reminiscent of state authority, no matter how arbitrary. Schmitt's theory rejects truth as a value foundational to the judicial system, only to adopt a continuously authoritarian conception of this system that cannot be reconciled with liberal democratic values. If constitutions are indeed based on some form of authority or violence, at least historically, this does not and should not entail that all subsequent acts of the state replicate this violence. See Carl Schmitt, Political Theology: Four Chapters on the Concept of Sovereignty, translated by George Schwab (Chicago: University of Chicago Press, 1985); William E Scheuerman, "Down on Law: The Complicated Legacy of the Authoritarian Jurist Carl Schmitt", Boston Review (2001), online: Boston Review <http://new.bostonreview.net/BR26.2/scheuerman.html>. 


\section{CONCLUSION}

In identifying two important gaps, and, by extension, two potential avenues for future research, in the literature on civil procedure reform, we have drawn attention to the concept of formal stability in the law, its role in promoting dignity and agency for individuals governed by law, and its association with public adjudication. The literature on civil procedure tends to assume that legal norms represent a fixed term in adjudication. Our discussion of the issue of indeterminacy, however, emphasized the process of judicial articulation of legal norms, a phenomenon that legal positivism and legal interpretivism have traditionally overlooked, and an added value of public adjudication that is not present in private forms of dispute resolution. The formalization of legal norms through a public process of adjudication stabilizes the expectations of individual subjects of law and, in turn, permits them to plan their lives and social interactions.

The potential for public adjudication to bring about stability for individuals governed by law is enhanced through judicial rituals and architecture, and the lack of scholarship on this point constitutes another gap in the literature on civil justice reform. In this article, we have highlighted the importance of judicial rituals and architecture in identifying fundamental principles of justice and their ability to convey these values in a stable and accessible fashion. Civil justice reform programs should pay more attention to the role played generally by form in stabilizing the law, particularly through non-textual expressions such as judicial rituals and architecture.

Looking toward the future of civil justice, further research might focus on what we have identified as the "arbitration puzzle" and on dispute resolution processes that are relatively less formal and elaborate, as parties are increasingly offered the opportunity to take an active role in private dispute resolution rather than remaining passive spectators in public adjudicative proceedings. The means by which public adjudication may serve to promote the stability of the law, and, by consequence, the dignity and agency of individuals, must be taken seriously when contemplating new ways to render the administration of public justice more efficient as well as when assessing the effectiveness of ADR mechanisms. 